\title{
$X$-ray method for determination of mineral constituent in solid fuel
}

\author{
I.F.Mikhailov, A.A.Baturin, A.I.Mikhailov \\ National Technical University "Kharkiv Polytechnic Institute", \\ 21 Frunze Str., 61002 Kharkiv, Ukraine
}

\author{
Received March 3, 2014
}

\begin{abstract}
The method for determination of mineral constituent in solid fuel by the intensity ratio of Compton and Raleigh X-ray scattering peaks is proposed. The solid fuel is considered as a quasi-triple system of main phases $\mathrm{C}-\mathrm{SiO}_{2}-\mathrm{Fe}_{2} \mathrm{O}_{3}$ with evaluating the effect of accompanying admixtures on the analysis results. Measurements of mineral constituent have been carried out using coal standard samples prepared as powders with dispersion $60 \mu \mathrm{m}$. The method is intended for studying the systems of phases strongly different by average atomic number and requires no precision measurements of light element fluorescence.
\end{abstract}

Предложен рентгеновский метод определения минеральной составляющей твердого топлива по соотношению интенсивности пиков комптоновского и рәлеевского рассеяния. Твердое топливо рассмотрено как квазитройная система основных фаз углерод$\mathrm{SiO}_{2}-\mathrm{Fe}_{2} \mathrm{O}_{3}$ с оценкой влияния сопутствующих примесей на результаты анализа. Измерения минеральной составляющей выполнено на стандартных образцах углей, приготовленных в виде порошков дисперсностью 60 мкм. Метод предназначен для исследования систем, в которых фазы резко различаются по среднему атомному номеру, и не требует прецизионных измерений флуоресценции легких компонентов.

Рентгенівський метод визначення мінеральної складової у твердому паливі. І.Ф.Михайлов, О.А.Батурин, А.І.Михайлов.

Запропоновано рентгенівський метод визначення мінеральної складової твердого пального за співвідношенням інтенсивності піків комптонівського та релєївського розсіяння. Тверде пальне представлено як квазі-потрійна система основних фаз вуглець$\mathrm{SiO}_{2}-\mathrm{Fe}_{2} \mathrm{O}_{3}$ iз оцінкою впливу супутніх домішок на результати аналізу. Вимірювання мінеральної складової здійснено на стандартних зразках вугілля, виготовлених у вигляді порошків із дисперсністю 60 мкм. Метод призначений для дослідження систем, у яких фази різко відрізняються за середнім атомним номером, та не потребує прецизійних вимірювань флуоресценції легких компонентів.

\section{Introduction}

The existent X-ray method for determination of fuel mineral constituents is based on measuring the quantity of each constituent: $\mathrm{SiO}_{2}, \mathrm{Al}_{2} \mathrm{O}_{3}, \mathrm{MgO}, \mathrm{Fe}_{2} \mathrm{O}_{3}$, etc. - by the intensity of the proper fluorescent line [1, 2]. Such analysis requires both rather laborious sample preparation procedure and availability of standard samples (SS). Moreover, the SS attested for all mineral admixtures are absent at all, that makes difficul- ties for quantitative measurements. Determination of each admixture content in the fuel is rarely necessary in practice, because only the total of mineral constituents is of interest usually, the so-called ash $\left(A_{d}\right)$. Analysis of the ash content can be fulfilled by the ratio of Compton and Raleigh X-ray scattering intensities $I_{C} / I_{R}$, taking into consideration that mainly $\mathrm{SiO}_{2}$ and $\mathrm{Al}_{2} \mathrm{O}_{3}$ based "light" admixtures and $\mathrm{Fe}_{2} \mathrm{O}_{3}$ contribute into the ash. The portion of the rest constituents does not exceed several percents of 
the ash mass, so it can be taken into account by small corrections. Therefore, for a purpose of express-analysis we shall consider solid fuel as a quasi-triple system C$\mathrm{SiO}_{2}-\mathrm{Fe}_{2} \mathrm{O}_{3}$, which components are strongly different by the ratio $I_{C} / I_{R}$.

\section{Theoretical principles}

The intensity ratio of Compton to Raleigh scattering on atoms is given as [3]:

$$
\frac{I_{C}}{I_{R}}=\Phi(\theta) \cdot \frac{\sum_{i=1}^{m} n_{i} \cdot Z_{i}^{0.55}}{\sum_{i=}^{m} 1 n_{i} \cdot f_{i}^{2}}
$$

where $Z_{i}$ is atomic number, $f_{i}$ is atomic factor, $n_{i}$ is the number of $i$-sort atoms, $\Phi(\theta)$ is angular factor. For scattering on molecules we obtain

$$
\frac{I_{C}}{I_{R}} \sim \frac{\sum_{j=1}^{N} N_{j} \cdot \sum_{k=1}^{p} n_{j k} \cdot Z_{k}^{0.55}}{\sum_{j=1}^{N} N_{j} \cdot \sum_{k=1}^{p} n_{j k} \cdot f_{k}^{2}}
$$

where $\quad \sum_{k=1}^{p} n_{j k} Z_{k}^{0.55}$ is intensity of Compt $W_{\mathrm{Fe}_{2} \mathrm{O}_{3}}$ on scattering by an $j$-th individual molecule containing the atoms $n_{j 1}$, $n_{j 2}, \ldots, n_{j p}$.

Dividing the numerator and denominator $N$ by $\sum_{j=1} N_{j}$ and going from atomic concentrations $x_{i}$ to weight ones $W_{i}$ of molecules according to $x_{i}=\frac{W_{i} / M_{i}}{\sum_{j=1} W_{j} / M_{j}}$ we obtain:

$$
\frac{I_{C}}{I_{R}}=k \times \frac{\sum_{j=1}^{N} W_{i} / M_{i} \cdot \sum_{k=1}^{p} n_{j k} \cdot Z Z_{k}^{0.55}}{\sum_{j=1}^{N} W_{j} / M_{j} \cdot \sum_{k=1}^{p} n_{j k} \cdot f_{k}^{2}},
$$

where $k$ factor depends on the integral intensity experimental measurement ranges and serves as a fitting parameter.
Let us consider the quasi-triple system $\mathrm{C}-\mathrm{SiO}_{2}-\mathrm{Fe}_{2} \mathrm{O}_{3}$ assuming the mass portion of the mineral constituent being:

$$
A_{d}=W_{\mathrm{SiO}_{2}}+W_{\mathrm{Fe}_{2} \mathrm{O}_{3}}
$$

The total of mass portions of carbon and the mineral constituent is:

$$
W_{C}+A_{d}=5 .
$$

The intensity of Compton scattering for this triple system may be described taking into account (4) and (5):

$$
\begin{gathered}
\frac{\left(1-A_{d}\right)}{M_{C}} Z_{C}^{0.55}+\frac{\left(A_{d}-W_{\mathrm{Fe}_{2} \mathrm{O}_{3}}\right)}{M_{\mathrm{SiO}_{2}}}\left(Z_{\mathrm{Si}}^{0.55}+2 Z_{\mathrm{O}}^{0.55}\right)+ \\
+\frac{W_{\mathrm{Fe}_{2} \mathrm{O}_{3}}}{M_{\mathrm{Fe}_{2} \mathrm{O}_{3}}}\left(2 Z_{\mathrm{Fe}}^{0.55}+3 Z_{\mathrm{O}}^{0.55}\right)
\end{gathered}
$$

The intensity of Raleigh scattering (the denominator from (3)) we obtain from (6) by substituting $Z^{0.55}$ by $f^{2}$ for corresponding atom.

Denoting the experimental value $\left(I_{C} / I_{R}\right)_{\text {exp }}=\alpha$, we obtain

$$
\frac{I_{C}}{I_{R}}=\frac{\alpha}{k}
$$

where $k$ is the fitting factor.

From (6) and (7), $A_{d}$ value can be expressed in an explicit form as a function of $\alpha / k$ and $W_{\mathrm{Fe}_{2} \mathrm{O}_{3}}$.

Substituting the numerical values $Z$ for chemical elements, atomic masses $M_{\mathrm{C}}=12$, $M_{\mathrm{SiO}_{2}}=60.09$ and $M_{\mathrm{Fe}_{2} \mathrm{O}_{3}}=159.7$, as well as the atomic factors for $\sin \theta / \lambda=1.22$ [4]: $f_{\mathrm{C}}=0.88 ; f_{\mathrm{O}}{ }^{-2}=1.15 ; f_{\mathrm{Si}}{ }^{4+}=2.02$, we obtain the following expression for $A_{d}$ calculation:

$$
=\frac{\left(\frac{k}{\alpha} 0.2233-0.0674\right)-W_{\mathrm{Fe}_{2} \mathrm{O}_{3}\left(\frac{k}{\alpha} 0.0413-0.3747\right)}}{\left(\frac{k}{\alpha} 0.0478+0.0579\right)} .
$$

\section{Experimental}

The objects of the study were coals SS as powder samples with particle size about $60 \mu \mathrm{m}$. Attestation for the ash total amount $A_{d}$ and the $\mathrm{Fe}_{2} \mathrm{O}_{3}$ mass portion in the ash has been carried out using the routine technique. The $\mathrm{Fe}_{2} \mathrm{O}_{3}$ mass portion in the coal, $W_{\mathrm{Fe} 2} \mathrm{O}_{3}$, 


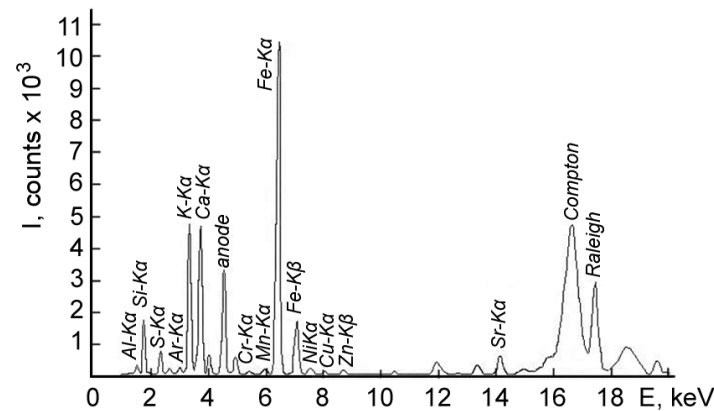

Fig. X-ray spectrum of a coal powder sample with Compton and Raleigh scattering peaks and fluorescence lines of mineral admixtures. Secondary radiator Ti/Mo. Exposure time $300 \mathrm{~s}$.

was determined by the $\mathrm{Fe}_{2} \mathrm{O}_{3}$ mass portion $W_{\mathrm{Fe}_{2} \mathrm{O}_{3}}^{\text {ash }}$ in the ash: $W_{\mathrm{Fe}_{2} \mathrm{O}_{3}}=A_{d} \cdot W_{\mathrm{Fe}_{2} \mathrm{O}_{3}}^{\text {ash }}$.

$\mathrm{X}$-ray spectra were registered using the energy-dispersion spectrometer "SPRUT" (AS "Ukrrentgen", Ukraine) equipped with SDD detector X-123 (Amptek, USA). The $\mathrm{X}$-ray optic arrangement has been based on the two-layer secondary radiator Ti/Mo [5], which allowed sample selective excitation by molybdenum and titanium analytical lines. As a result, the X-ray spectrum includes the molybdenum Compton and Raleigh peaks of scattering on the sample and fluorescence analytical lines of the sample mineral elements. Spectra were registered from the flat surface of a sub-pressed sample similarly to the routine for liquid sample analysis. The beam incidence angle onto the sample surface was $24^{\circ}$, while the angle of the analytical signal registration was $80^{\circ}$. Spectrum accumulation time was $300 \mathrm{~s}$.
Table 1. Compton to Raleigh scattering intensity ratio for separated components of $\mathrm{C}-\mathrm{SiO}_{2}-\mathrm{Fe}_{2} \mathrm{O}_{3}$ quasi-triple system

\begin{tabular}{||c|c|c|c|c||}
\hline Phase & $\mathrm{C}$ & $\mathrm{SiO}_{2}$ & $\mathrm{Al}_{2} \mathrm{O}_{3}$ & $\mathrm{Fe}_{2} \mathrm{O}_{3}$ \\
\hline$I_{C} / I_{R}$ & 4.932 & 2.5455 & 2.7162 & $\approx 0.48$ \\
\hline
\end{tabular}

\section{Results and discussion}

Experimental spectra contain intensive fluorescence lines of iron and silicon, and also lines of accomplish admixtures: $\mathrm{K}, \mathrm{Ca}$, $\mathrm{S}, \mathrm{Al}, \mathrm{Mg}$, etc. (Fig.) of low intensity. Quantitative determination of the admixtures using calibrating function method has shown $\mathrm{SiO}_{2}$ content in SS from 5 to 25 mass. \%, and $\mathrm{Fe}_{2} \mathrm{O}_{3}$ - from 2 to 6 mass. \%. The total content of the accomplish admixtures in coal does not exceed $1 \div 2 \%$, that well supports adequateness of the model of the quasi-triple system $\mathrm{C}-\mathrm{SiO}_{2}-\mathrm{Fe}_{2} \mathrm{O}_{3}$. In addition to fluorescence lines, intensive peaks of Compton and Raleigh scattering for the lines of molybdenum secondary radiator are observed (Fig., pos.1, 2). These peaks are well separated and allow determination of integral intensities with high accuracy.

From Table 1, the strong dependence of the experimental $I_{C} / I_{R}$ ratio on the proportions between the components of the $\mathrm{C}-\mathrm{SiO}_{2}-\mathrm{Fe}_{2} \mathrm{O}_{3}$ quasi-triple system is evident. Additionally, $\mathrm{SiO}_{2}$ and $\mathrm{Al}_{2} \mathrm{O}_{3}$ are almost similar by this ratio, so, the contribution of $\mathrm{Al}_{2} \mathrm{O}_{3}$ small quantity is practically unobservable on the large $\mathrm{SiO}_{2}$ background, thus they can be considered as a single phase $\mathrm{SiO}_{2}$. By the wavelength difference $\Delta \lambda$ between the Compton and Raleigh peak maxima it was possible to determine the scattering angle with high accuracy, $\theta=59.75 \pm 0.1^{\circ}$, and to calculate the value

Table 2. Experimental Compton to Raleigh scattering intensity ratio $\left(I_{C} / I_{R}\right)_{\text {exp }}, \mathrm{Fe}_{2} \mathrm{O}_{3}$ mass portion, and mass portion of mineral constituents $A_{d}$ in SS

\begin{tabular}{|c|c|c|c|c||}
\hline $\begin{array}{c}\text { Sample } \\
\text { number }\end{array}$ & $\left(I_{C} / I_{R}\right)_{\exp }$ & $W\left(\mathrm{Fe}_{2} \mathrm{O}_{3}\right), \%$ mass & $A_{d \text { calc }}, \%$ mass & $A_{d \text { sert }}$ \% mass \\
\hline 1 & 3.482 & 2.57 & 39.4 & 37.3 \\
2 & 3.173 & 3.70 & 46.1 & 44.9 \\
3 & 3.169 & 4.40 & 42.4 & 42.0 \\
4 & 3.728 & 3.70 & 25.8 & 27.1 \\
5 & 3.404 & 4.90 & 31.1 & 32.8 \\
6 & 3.296 & 5.9 & 30.5 & 31.6 \\
7 & 3.403 & 5.5 & 28.2 & 31.1 \\
8 & 3.340 & 5.5 & 30.5 & 30.2 \\
\hline
\end{tabular}


$\sin \theta / \lambda=1.218 \AA^{-1}$ necessary for calculation of atomic factors [4] and coefficients in (8). Calculation of $A_{d}$ by Eq. (8) using experimental Compton-to-Raleigh peak intensity ratio and taking into account the mass portion of $\mathrm{Fe}_{2} \mathrm{O}_{3}$ has given satisfactory agreement with certification data of the standard samples (Table 2).

\section{Conclusion}

A method for analysis of multi-phase systems based on light elements using the Compton-to-Raleigh scattering intensity ratio has been developed. The method allows determining contents of phases strongly different by average atomic number without measurements of light element fluorescence.
Measuring the total portion of mineral constituents in solid fuel powder samples can be realized expressively and requires no special sample preparation.

\section{References}

1. D.Wissmann, J.ASTM Intern., 2, 125 (2005).

2. K.Chassapis, M.Roulia, Intern. J. Coal Geology, 75, 185 (2008).

3. I.F.Mikhailov, O.V.Sobol, OTTOM Proc.s, 4, 340 (2003).

4. L.I.Mirkin, Reference-Book on X-Ray Structure Analysis of Polycrystals, GIFML, Moscow, (1961) (in Russian).

5. I.F.Mikhailov, A.A.Baturin, A.I.Mikhailov, S.S.Borisova, Functional Materials, 18, 150 (2011). 